ПЕДАГОГИЧЕСКАЯ ПСИХОЛОГИЯ

УДК 37.015 .3

doi: 10.21702/rpj.2016.3.4

\title{
МЕЖКУЛЬТУРНАЯ СОЦИАЛЬНО-ПСИХОЛОГИЧЕСКАЯ АДАПТАЦИЯ СТУДЕНТОВ В ПОЛИЭТНИЧЕСКОМ ОБРАЗОВАТЕЛЬНОМ ПРОСТРАНСТВЕ ВУЗА
}

\author{
Ирина Владимировна Абакумова \\ доктор психологических наук, профессор, член-корреспондент РАO \\ Южный федеральный университет \\ 2. Ростов-на-Дону, Россия \\ E-mail:abakira@mail.ru \\ Лаура Цараевна Кагермазова \\ доктор психологических наук, профессор, академик РАЕН \\ Кабардино-Балкарский государственный университет им. Х. М. Бербекова \\ 2. Нальчик, Россия \\ E-mail: laura07@yandex.ru \\ Зоя Шаваловна Генердукаева \\ старший преподаватель \\ Грозненский государственный нефтяной технический университет \\ 2. Грозный, Россия \\ E-mail: generzoya@mail.ru
}

Исследование выполнено в рамкахгосударственногозадания Министерства образования и науки РФ, задание № 28.125.2016/HM

В статье поднимаются проблемы межкультурной социально-психологической адаптачии студентов, обучающихся в российских вузах. Рассматривается актуальность внедрения программы межкультурной социально-психологической адаптации иностранных студентов. Описаны логическая структура программы, ее концептуальная основа, методологические принципы, условия реализации, используемые методы.

Разработан портрет иностранного студента, в качестве структурных компонентов которого выделены сочиальные и психологические особенности. Предложены и описаны направления работы в рамках реализации программы межкультурной социально-психологической адаптации иностранных студентов. Выработаны рекомендации по оптимизации процесса адаптации в условиях образовательной среды вуза. 
В работе представлены актуальные вопросы:межкультурной коммуникации, лингвокультурологии, психологии, социологии и массовой коммуникации, знание которых позволит эффективно и грамотно организовать межкультурную адаптацию иностранных студентов в едином образовательновоспитательном пространстве международно-ориентированного вуза, с учетом богатого опыта работы Кабардино-Балкарского государственного университета им. Х. М. Бербекова, в челях создания предпосылки возможной будущей деятельности в области формирования единой образовательной среды в рамках Болонского прочесса.

Предлагаются современные технологии сочиально-психологического сопровождения межкультурной адаптации обучающихся иностранных граждан в условиях образовательного пространства вуза.

Сочиально-психологическое сопровождение иностранных студентов представляет собой целостную, системно организованную деятельность, в рамках которой создаются благоприятные условия для успешного функционирования сопровождаемого субъекта. Это наиболее оптимальный способ, способствующий успешной межкультурной адаптации иностранных студентов, позволяющий создать условия для сохранения культурной направляющей студентов как представителей своей страны, актуализировать имеющиеся социокультурные знания, получить информацию о многообразии и самоценности разнообразных культур, повысить уровень межкультурной компетентности, осознать необходимость толерантного отношения к другим культурам и наличие общечеловеческих ценностей.

Ключевые слова: адаптация, социальная адаптация, сочиально-nсихологическое сопровождение, личность, межкультурная коммуникация, мотивация, психодиагностика, социокоммуникативные условия, социализачия, полиэтнические группы.

Для цитирования: Абакумова И. В., Кагермазова Л. Ц., Генердукаева 3. Ш. Межкультурная социально-психологическая адаптация студентов в полиэтническом образовательном пространстве вуза // Российский психологический журнал. - 2016. - Т. 13. - № 3. - С. 53-72. 


\title{
THE INTERCULTURAL SOCIO-PSYCHOLOGICAL ADAPTATION OF STUDENTS IN THE POLYETHNIC EDUCATIONAL SPACE OF THE INSTITUTE OF HIGHER EDUCATION
}

\author{
Irina Vladimirovna Abakumova \\ Doctor of Psychology, Professor, Corresponding Member of the Russian Academy of Education \\ Southern Federal University \\ Rostov-on-Don, Russia \\ E-mail: abakira@mail.ru \\ Laura Tsaraevna Kagermazova \\ Doctor of Psychology, Professor, Academician of the Russian Academy of Natural Sciences \\ Kabardino-Balkarian State University named after H. M. Berbekov \\ Nalchik, Russia \\ E-mail: laura07@yandex.ru

\section{Zoia Shavalovna Generdukaeva \\ Senior Lecturer \\ Grozny State Oil Technical University \\ Grozny, Russia \\ E-mail: generzoya@mail.ru}

\section{Acknowledgments}

The study is supported the Ministry of Education and Science of the Russian Federation, assignment no. 28.125.2016/HM

The paper discusses the problems of the intercultural socio-psychological adaptation of students studying in Russian institutes of higher education. The implementation of the program of the intercultural socio-psychological adaptation of foreign students is of special relevance. The article describes the logical structure of the program, its conceptual framework, methodological principles, conditions of implementation, and applied methods.

The authors (a) developed a foreign student's portrait, (b) distinguished structural components (social and psychological characteristics) of this portrait, (c) described areas of work on the implementation of the intercultural sociopsychological adaptation of foreign students, and (d) developed recommendations for optimizing the process of adaptation in the educational environment of the institute of higher education. 
The paper focuses on urgent issues of intercultural communication, linguoculturology, psychology, sociology, and mass communication. To create the necessary prerequisites for possible future activities in the field the unified educational environment in the framework of the Bologna process, the consideration of these problems might be helpful in the effective and competent organization of the intercultural adaptation of foreign students in the unified educational space of the international-oriented institute of higher education, taking into account the rich experience of Kabardino-Balkarian State University named after H. M. Berbekov.

The authors offered modern methods of socio-psychological support for the intercultural adaptation of foreign students in the educational space of the institute of higher education.

Socio-psychological support for foreign students is an integral, systematically organized activity, which creates favorable conditions for the successful functioning of the person. This is the best way contributing to successful intercultural adaptation of foreign students. Socio-psychological support for foreign students creates conditions for the preservation of the cultural guide of students as representatives of their country, actualization of the existing socio-cultural knowledge, getting the information about the diversity and value of various cultures, increasing the level of intercultural competence, understanding of the necessity of tolerant relation to other cultures and existence of universal values.

Keywords: adaptation, social adaptation, socio-psychological support, personality, intercultural communication, motivation, psychodiagnostics, sociocommunicative conditions, socialization, multi-ethnic group.

For citation: Abakumova I. V., Kagermazova L. Ts., Generdukaeva Z. Sh. The Intercultural Socio-Psychological Adaptation of Students in the Polyethnic Educational Space of the Institute of Higher Education. Russian Psychological Journal, 2016, V. 13, no. 3, pp. 53-72.

\section{Введение}

Одной из перспективных задач системы высшего образования нашей страны является подготовка иностранных студентов в качестве высококвалифицированных специалистов. «Успешная реализация образовательного процесса в данном направлении может способствовать формированию позитивного имиджа нашей страны на международной арене, укреплению ее позиций в мировом образовательном пространстве, развитию межкультурного диалога» [8].

В Федеральной программе Российской Федерации «Развитие образования» отмечается, что до 2020 г. количество студентов-иностранцев, обучающихся в России, должно составить $10 \%$. Для РФ количество 
студентов-иностранцев является основной характеристикой интернационализации. Количество обучающихся, приезжих из-за рубежа, выросло до 158,4 тыс. человек в 2013/2014 уч. г. Рост осуществляется за счет приезда обучающихся из дальнего и ближнего зарубежья.

В связи с этим, значимой становится реализация программ и подпрограмм по социально-психологическому сопровождению адаптации иностранных студентов к изменяющимся культурным и психологическим особенностям с целью успешного процесса межэтнической адаптации в «обучающей, социально-психологической среде» [7, с. 311; 17, с. 46].

Студенты-иностранцы, обучающиеся на территории РФ, должны приспособиться к большому количеству новых характеристик страны обучения: условию обучения в вузе, проживанию в общежитии, социальной ситуации окружения, отсутствию родственников, общению на ином языке и т. д. Проблемы, с которыми студенты-иностранцы встречаются, имеют выраженный характер национальных, этнических, культурных, социально-бытовых особенностей $[7,19]$. Студентам, обучающимся в другой стране, необходимо психологическое сопровождение в осуществлении коммуникации (важно в тех случаях, когда личность оказывается в иной культурной и языковой среде), в осознании иной социо-этнокультурной среды [3, 13].

Цель статьи: программирование вопросов межэтническо-культурной адаптации студентов-иностранцев в новой образовательной среде высшей школы через социально-психолого-педагогическую поддержку студентов иностранных студентов, включающее управленческую деятельность, где отражаются благоприятные условия для эффективного функционирования приезжего учащегося в разном поле деятельности [5].

«Сопровождение» определяется как объединение всех участников учебно-воспитательного процесса (учащихся, преподавателей, тьютеров) или участников (подструктур) образовательного учреждения (методической и управления по воспитательной работе). Основное понятие «сопровождение» полинаправленно. Э. Ф. Зеер отмечает данное понятие «целостным процессом изучения, формирования, развития и коррекции становления личности. В данном случае под "сопровождением" имеется в виду помощь учащемуся в становлении развития и ответственность за свое поведение и деятельность. Важным аспектом является внутренний план учащегося, а значит, он имеет право на самостоятельный выбор действия и несения за него ответственности» [4, с. 11-20].

Психолого-педагогическая поддержка студентов-иностранцев может реализовываться в рамках основных психологических подходов, опираться на научно-психологические методики, направленные на предупреждение и разрешение вопросов, возникающих на данном этапе становления личности 
приезжего. В свою очередь, данный метод способствует эффективному межэтническому и культурному привыканию и на личностном, и на межгрупповом уровне, общественно-приемлемыми методами подготавливает почву для самопознания и самосознания своей культуры и культуры других национальностей [1]. Адаптационный процесс - это сложное социальное явление, которое включает в себя: социально-психологические, политические, межкультурные, социально-педагогические аспекты [3].

Особенности «сопровождения студентов-иностранцев к иной социальной ситуации среды описывали Вей Син, И. А. Гребенникова, И. Л. Жирнова, О. А. Иванова, Т. В. Киящук, И. А. Мнацаканян, Т. К. Фомина. О. А. Иванова характеризует межкультурную адаптацию через проблему формирования учебно-профессиональной Я-концепции иностранных студентов» [6].

И. А. Гребенникова определяет условия, критерии, эффективные движущие силы для определения успешных правил психолого-педагогической адаптации студентов-иностранцев в образовательной среде [1]. И. А. Мнацаканян выделяет «программу подготовки обучающихся к эффективному межкультурному диалогу, который лежит в основе преодоления трудностей межкультурной адаптации и взаимодействия». Следует заметить, что единых теорий, позволяющих вести учет основных условий, межэтнической адаптации студентов-иностранцев, мало [9].

Особенности содержания программы социально-психологической и социально-педагогической поддержки адаптации к разным культурам студентов-иностранцев решаются в следующих аспектах: поддержка иностранных студентов в адаптации к проживанию, учебной деятельности в стране пребывания; знания иностранных студентов духовного и культурного достояния страны, прошлого опыта разных культур; приобщение студентов-иностранцев в жизнедеятельность университета, республики, края; развитие толерантности к установкам, ценностям, мировоззрению в иных этносах, традициях, обычаях; адекватность к различным условиям жизнедеятельности. В Кабардино-Балкарском государственном университете им. Х. М. Бербекова (КБГУ) учатся и проходят языковые практики представители следующих стран: Турция, Сирия, Иордания, Марокко, Пакистан, Корея, Таджикистан, Украина, Израиль и др.

Социально-психологические проблемы, с которыми сталкиваются иностранные студенты:

- вступление в социокультурное информационное поле;

- вступление в новое социальное окружение (учебная деятельность);

- неадекватно высокие психофизические нагрузки (информационная, эмоциональная информация, адаптация).

Для высокой продуктивности процесса межкультурной, 
социально-психолого-педагогической адаптации действует «Программа межкультурной социально-психологической адаптации студентов в полиэтническом образовательном пространстве КБГУ» [8, с. 262]. Основной целью программы мы считаем поддержку благополучного процесса межкультурной адаптации иностранных студентов в новых социокультурных условиях, развитие и формирование у студентов важных психолого-педагогических особенностей, формирующих успешную межкультурную толерантность. Данная программа осуществляет воспитание положительного этнического самопознания, толерантности, межкультурного единства.

Концептуальная основа программы: личностно-ориентированный подход (теория), направленный на знание индивидуальных характеристик студентов-иностранцев (О. С. Газман, И. А. Зимняя, А. Н. Леонтьев, С. Л. Рубинштейн и др.).

Общеметодологические принципы исследования: принципы деятельностного подхода (Л. С. Выготский), принцип деятельности (А. Н. Леонтьев, С. Л. Рубинштейн), активности (К. А. Абульханова, В.Н.Мясищев, А. В. Петровский).

Данная работа решает следующие задачи:

- содействие иностранным студентам в адаптации к условиям проживания, обучения в КБР;

- обучение иностранных студентов с духовно-культурным достоянием, социально-историческим наследием русской, кабардинской и балкарской культур;

- рост межкультурной компетентности иностранных студентов;

- введение иностранных студентов в общественно-культурную деятельность вуза, города, республики;

- воспитание толерантности к убеждениям, ценностям, мировоззрению к различным культурам;

- воспитание культурного самосознания и самопознания;

- увеличение комфортности для каждого иностранного студента в условиях обучения и проживания в полиэтнической, поликультурной среде.

Факторы функционирования программы:

- особенности взаимодействия со студентами-иностранцами;

- учитывание принципов деятельности в учебно-воспитательном процессе;

- знание социокультурных, психоэтнических свойств иностранных студентов как представителей поликультур;

- индивидуальный подход к студентам-иностранцам как к активным представителям учебно-воспитательной деятельности.

В работу включены:

- обучающие семинары по межкультурной коммуникации в диалоге культур; 
- межкультурные обучающие ситуации;

- экскурсионно-практические мероприятия;

- социально-психологические деловые игры, способствующие эффективной межкультурной коммуникации, уменьшению уровня тревожности, агрессивности, раздражительности и др.;

- беседы;

- обучающие занятия по толерантности;

- обучающий семинар по развитию культурного самосознания, самопознания;

- полиэтнический и межкультурный диалог.

\section{Основные направления программы и их реализация}

Основные направления программы: 1) социальная адаптация; 2) психологическая адаптация; 3) межкультурная адаптация, 4) межкультурное взаимодействие; 5) социально-психологическая помощь во время обучения; 6) мониторинг; 7) лингвистическая адаптация; 8) методическое сопровождение.

В результате рассмотрения отечественных и зарубежных источников по вопросам приспособления студентов-иностранцев, эмпирического исследования, определен принцип общения студента-иностранца с социальными и психологическими характеристиками:

\section{І. Социальные:}

1. Отсутствие принципов поведения в новых социокультурных условиях, налаживания учебной деятельности.

2. Культурная дистанционность с партнерами по общению - представителями русской и других культур.

3. Отсутствие уровня развития межкультурной компетентности.

4. Узость контактов с социальным окружением.

II. Психологические:

1. Наличие стабильного отношения к будущей профессиональной деятельности.

2. Стабильная потребность знать язык специальности.

3. Состояние психологической, эмоциональной напряженности.

4. Единство этнической терпимости и этнического самопознания и самосознания.

Программа по сопровождению межкультурной адаптации иностранных студентов характеризуется тремя взаимосвязанными направлениями профессиональной деятельности: 1) развитием особенностей поведения в бытовых условиях у студентов-иностранцев; 2) воспитанием личностных качеств студентов-иностранцев (терпимость, самоидентификация), устранением 
отрицательных особенностей (агрессия, тревожность, культурная дистанция); 3) воспитанием межкультурной компетентности студентов-иностранцев.

\section{1. Развитие особенностей поведения в бытовых условиях у студен-} тов-иностранцев. Приезжая в Нальчик, студенты-иностранцы приспосабливаются к неизвестной обстановке, противоположной родной. Обстановка и условия жизнедеятельности в РФ являются для студента-иностранца новыми. Возникающие проблемы определяются отсутствием социальных навыков, которые помогли бы эффективному процессу адаптации. Данные трудности - дефицит информации о стране пребывания, правилах поведения в иной культуре. Наиважнейшей работой со студентами-иностранцами является знаниевая работа и целенаправленное развитие навыков самостоятельной жизни в вузе, общежитии, городе.

Осуществление первого направления возможно через:

- обучение студентов-иностранцев законодательству РФ, Уставу, структуре, истории университета, поведению в учебных корпусах, общежитии и на территории студенческого городка университета;

- обучение студентов-иностранцев картам-схемам, маршрутам следования, правилам езды в общественном транспорте;

- помощь в выборе товаров с наилучшим соотношением цены и качества;

- показ мест проведения досуга в стенах университета в бесплатном режиме (библиотеки, интернет-центр, спорткомплекс КБГУ, центры национальной культуры кабардинцев, балкарцев, русских).

2. Воспитание личностных качеств студентов-иностранчев (терпимость, самоидентификация), устранение отрицательных особенностей (агрессия, тревожность, культурная дистанция):

- «создание условий для актуализации этнической идентичности, стимулирование процессов этнического и культурного самоопределения;

- формирование и развитие толерантности иностранных студентов (уважение других этнических групп, готовность к совместной деятельности, обмену идеями и установками с представителями русской и других культур);

- создание условий, в рамках которых постепенно будет снижаться уровень негативных особенностей иностранных студентов, затрудняющих процесс их межкультурной адаптации (культурный шок, тревожность, культурная дистанция)» [18].

3. Воспитание межкультурной компетентности студентов-иностранцев. Данное условие выполнимо в процессе межкультурного диалога, межкультурного взаимодействия, устранения трудностей в коммуникации с представителями разных культур:

- в процессе межкультурного взаимодействия студентов-иностранцев друг с другом, с сотрудниками университета; 
- в наличии условий взаимопроникновения культур, воспитания настоящего интереса к иной культуре;

- в наличии условий для формирования социокультурных знаний студентов-иностранцев, потребности к когнитивной деятельности;

- в развитии умений коммуникативистики, эмпатии и толерантности;

- в воспитании умений передавать культурные обычаи различных стран [15].

Важными элементами работы со студентами-иностранцами являются: создание режима деятельности студента; создание списка медицинских препаратов для первой помощи при заболеваниях разного уровня; создание списка контактных данных сотрудников университета.

Эффективная адаптация дает возможность включению студента-иностранца в образовательную среду, что повышает статус подготовки студентов-иностранцев в университете. Студент овладевает психологическими знаниями и навыками, повышает уровень стрессоустойчивости и благополучия. Это самое важное условие, создающее положительный образ российского образования [14].

Общеметодологическую базу исследования определили культурно-историческая теория Л. С. Выготского, психосемантический подход в психологии (Л. С. Выготский, А. Н. Леонтьев, А. Р. Лурия, В. Ф. Петренко, В. П. Серкин) $[3,5,8]$.

Научным фундаментом работы стали исследования: социально-психо- педагогической адаптации студентов-иностранцев в образовательном пространстве разных этносов [2]; образов «типичного кабардинца (адыга, черкеса), балкарца, русского» и «типичного араба», «типичного турка» в представлениях иностранных и российских студентов [2, с. 23]; категории «счастье» в мировоззрениях студентов [7]; уровня индивидуального благополучия студентов-иностранцев; приспособления к культуре и коммуникативным особенностям других студентов.

Т. Г. Стефаненко отмечает, что «любой тип этнокультурного тренинга не является идеальным, и не существует универсальной модели тренинга на основе единого теоретического подхода. Вместе с тем, всегда нужно помнить, что программы тренинга не есть набор неформальных и не планируемых заранее актов взаимодействия представителей разных культур. Любая программа предполагает целенаправленные, методологически обоснованные усилия по налаживанию эффективного межкультурного диалога, хорошо спланированные специалистами по активным методам обучения совместно с экспертами - этнологами и этнопсихологами, знакомыми с широким кругом проблем, встающих перед человеком в поликультурной среде» $[4$, с. 15; 16, с. 128].

Межэтническое взаимопроникновение осуществимо при: обучении, ориентировании и психологических занятиях (тренинговых занятиях). 


\section{Программа проводится в следующих номинациях:}

I. Для иностранных студентов:

1. Обучающий семинар «Университет мой - КБГУ».

Цель: когнитивный уровень культуры, традиций, обычаев России, местной культуры и функциональной структуры КБГУ. Обучающий семинар включает три основных блока: 1) лекция-презентация (с применением видео- и аудиоматериалов) «Нальчик: вчера и сегодня» и ролевые тематические игры; 2) истории взаимодействия представителей двух и более культур, в ходе которого участники встречаются с определенной проблемой. Каждая история сопровождается альтернативными вариантами решения проблемы и просьбой выбрать наиболее успешный вариант ответа [2]; 3) лекция-презентация «Университет мой - КБГУ» (с использованием видеоматериалов), которая представляет собой знакомство с историей, структурой, организацией в КБГУ, бытовыми условиями общежитий и т. п.

2. Психологический семинар «Культура народов России: кабардинцев, балкарцев и русских».

Данный семинар является вторым этапом адаптации иностранных студентов к образовательному полю КБГУ, в местную культуру. Целью является межкультурная социально-психологическая адаптация иностранных студентов, начинающих обучение в КБГУ.

Местные студенты знакомятся с представителями другой культуры, увеличивают свой кругозор, воспитывают этническую толерантность. Данный семинар понижает стресс, межэтнические конфликты, способствует эффективной мотивации к обучению и адаптации к учебной деятельности.

3. Диагностика личностных качеств (особенности личности, адаптационные способности, уровень этнической толерантности).

4. Обучающие семинары «Российская культура кабардинцев, балкарцев и русских» (деловые игры, декоративно-прикладное искусство, национальная кухня, национальные праздники). Знакомство с центрами национальной культуры кабардинцев, балкарцев, русских КБГУ. Цель: культурная адаптация с помощью народного творчества. Искусство - это язык самопознания и самовыражения.

II. Для российских преподавателей, сотрудников, взаимодействующих с иностранными студентами, и студентов, проживающих в общежитии и обучающихся с иностранцами:

1. Семинар-тренинг межкультурной компетентности.

Для развития межкультурной компетентности в ходе семинара-тренинга решаются задачи: обучить традициям, ценностям и нормам других культур; расширить знания о других культурах, изучив этнические стереотипы; обучиться распознавать вербальные и невербальные сигналы представителей 
других культур; найти позитивные стороны культурных различий.

2. Психологический тренинг развития этнической толерантности.

Тренинг проводится спустя 2-3 месяца пребывания иностранных студентов в России, но возможна реализация и позже. Он больше ориентирован на тех студентов, которые каким-либо образом взаимодействуют (проживают, обучаются, общаются) с иностранными студентами, а также преподавателей, обучающих иностранных студентов, и сотрудников, осуществляющих с ними внеучебную деятельность [12].

Программа межкультурной социально-психологической адаптации студентов в полиэтническом образовательном пространстве КБГУ включает психолого-социокультурную работу со всеми участниками интернационализации: иностранными студентами, преподавателями и местными студентами. Все это очень важно для успешной социально-психологической адаптации студентов-иностранцев.

Успешность работы по сопровождению межкультурной адаптации иностранных студентов в значительной степени определяется наличием адекватных и корректных методов.

При построении программ социально-психологического сопровождения межкультурной адаптации иностранных студентов необходима систематизация практических программ и методов формирования навыков социального взаимодействия с представителями других культур. Должны быть созданы условия, в которых иностранные студенты научаются навыкам и способам поведения, которые позволят им адекватно взаимодействовать с представителями принимающей культуры и представителями других культур, сильно отличающимися по большинству параметров - религии, языку, традициям, ценностям [10].

Именно успешное использование многочисленных активных методов в социально-психологическом сопровождении позволяет формировать у иностранных студентов навыки взаимопонимания и взаимодействия с представителями различных культур в реальных ситуациях, достаточно высокий уровень межкультурной компетентности.

При реализации необходимо учитывать:

1. Социально-психологические качества студентов-иностранцев: этническую толерантность, мотивационную направленность на обучение, умение работать в команде.

2. Саму специфику студенческой жизни (саморазвитие и самореализацию, способствующие формированию творческих достижений студента, налаживанию межличностных отношений, а также повышению его профессионального роста).

3. Национальный состав группы. 
4. Особенности социально-бытового устройства жизни студентов.

Определиться с основными акцентами в работе по сопровождению адаптации иностранных студентов могут помочь опросы различных групп, задействованных так или иначе в образовательном процессе: иностранных студентов, русских студентов, преподавателей, сотрудников международных отделов вуза [11].

При организации и проведении подобных опросов следует выявить положительные и отрицательные оцениваемые обстоятельства жизни иностранных студентов в нашей стране. Как отмечает И. А. Поздняков, само проведение анкетирования иностранных студентов представляет собой элемент практической работы в области психологического сопровождения, т. к. внимание администрации вузов к проблемам студентов, проявленное в форме опросов, уже является фактором, способствующим адаптации у нас в стране [7].

Подводя итог, следует отметить, что работа с иностранными студентами по повышению их межкультурной адаптации является принципиально важной в организации образовательного процесса иностранных студентов в условиях новой культуры. Показателями правильного развития социальнопсихологических особенностей, влияющих на успешность межкультурной адаптации, являются эмоциональные состояния иностранных студентов (их субъективное благополучие). Положительные эмоции, которые студент испытывает в отношениях с сокурсниками, преподавателями, соседями по общежитию, удовлетворительное самочувствие, ощущение душевного комфорта - все это показатели успешной адаптации личности. Они могут выступать в качестве критериев диагностики эффективности социальнопсихологического сопровождения иностранных студентов. Неправильное же их воспитание может стать основой нарушений в межкультурной адаптации иностранных студентов.

Таким образом, чтобы адаптация проходила эффективно, и трудности, возникающие в данный период, были сведены к минимуму, иностранные студенты должны обладать достаточной информацией по проживанию и обучению в нашей республике; условия проживания и обучения должны быть комфортными, а отношения с преподавателями и однокурсниками доброжелательными, создающими положительные эмоции.

По итогам реализации программы социально-психологического сопровождения иностранных студентов ожидается, что они будут способствовать эффективной межкультурной адаптации иностранных студентов к новым социокультурным условиям, благоприятному «вхождению» их в образовательный процесс, новую культуру, формированию положительного опыта межкультурного взаимодействия с представителями различных культур, 
расширению представлений о культуре принимающей стороны и других культурах.

Также необходимо отметить, что внедрение системы социально-психологического сопровождения иностранных студентов в процесс их межкультурной адаптации может повысить привлекательность российских вузов и дать ощутимый экономический эффект, т. к. комфортная и безопасная среда обучения и проживания вдали от дома - один из определяющих факторов при выборе образовательной организации.

По оценкам специалистов, непосредственно обеспечивающих учебный процесс и социально-бытовое сопровождение иностранных студентов, психолого-педагогическая работа, проведенная в этой области, дает положительные результаты. Мы надеемся, что позитивная динамика будет наблюдаться и в будущем, и планируем реализацию программы в других учебных заведениях КБР.

Ожидаемые результаты реализации «Программы межкультурной социально-психологической адаптации студентов в полиэтническом образовательном пространстве КБГУ»:

- поддержка иностранных студентов и слушателей, обучающихся в КБГУ им. Х. М. Бербекова;

- увеличение межкультурной компетентности студентов, преподавателей КБГУ им. Х. М. Бербекова;

- увеличение привлекательности обучения КБГУ им. Х. М. Бербекова для студентов-иностранцев;

- разработка банка методических работ психологического сопровождения иностранных студентов, развитие деятельности центра «Психологический дискурс»;

- практико-ориентированное поле по программам подготовки бакалавров и магистров;

- применение инновационных технологий в работе с иностранными студентами;

- создание при КБГУ «Отдела психологического сопровождения для студентов».

Работа отдела направлена на оказание психологической помощи студентам КБГУ в ситуациях, связанных с личностными проблемами, трудностями в общении, адаптацией к новым условиям учебной деятельности, академической неуспеваемостью, стрессом.

Основная цель отдела - обеспечение психологического благополучия, гармоничного развития, сохранение и укрепление здоровья, повышение адаптивных возможностей студентов КБГУ. Психологическая помощь и поддержка в отделе оказывается бесплатно, анонимно и конфиденциально. 


\section{Основными задачами отдела являются:}

- оказание психологической помощи студентам, находящимся в состоянии эмоциональной дезадаптации и испытывающим высокий уровень психологического стресса, для их адаптации к новым условиям;

- профилактика состояний эмоциональной дезадаптации у студентов;

- развитие у студентов устойчивости к стрессу и формирование конструктивных навыков совладания с ним;

- повышение социальной компетентности студентов и развитие у них навыков эффективных коммуникаций и самоорганизации;

- оказание помощи студентам в проблемных и кризисных жизненных ситуациях;

- развитие у студентов способности к саморазвитию и самоопределению.

\section{Основные направления деятельности:}

- индивидуально-психологическое консультирование;

- психологическая диагностика;

- психовоспитательная работа.

\section{Выводы}

Таким образом, данная программа эффективна и может быть включена во все сферы жизнедеятельности студента-иностранца, включает в себя педагогическую, психологическую, социальную работу. Может реализовываться в разных условиях, в различных национальных, этнических составах, во всех учебных заведениях, в которых осуществляется обучение студентов-иностранцев. Эффективное применение программы будет формировать позитивную межкультурную адаптацию студентов-иностранцев к новым социо-психокультурным условиям пребывания, успешному включению в образовательный процесс, новую культуру, формированию положительного опыта межкультурного взаимодействия с представителями различных культур, расширению представлений о культуре данного вуза. Внедрение данного типа программ повышает привлекательность российских вузов и дает ощутимый экономический эффект, т. к. комфортная, безопасная среда обучения - один из определяющих факторов при выборе образовательного пространства.

Помимо всего этого, внедрение системы социально-психологического сопровождения иностранных студентов в процесс их межкультурной адаптации может повысить привлекательность российских вузов и дать ощутимый экономический эффект, т. к. дружественная, комфортная и безопасная среда обучения и проживания вдали от дома-один из определяющих факторов при выборе зарубежного образовательного маршрута. 


\section{Литература}

1. Абакумова И. В. Психологические технологии формирования антитеррористических ценностей в молодежной среде // Российский психологический журнал. - 2010. - Т. 7. - № 5-6. - С. 23-26.

2. Абакумова И. В., Гришина А. В. Отношение студентов к мигрантам как фактор и показатель этноконфессиональных установок современной молодежи // Российский психологический журнал. - 2013. - Т. 10. № 3. - С. 22-28.

3. Абакумова И. В., Ермаков П. Н. О становлении толерантности личности в поликультурном образовании // Вопросы психологии. - 2003. № 3. - С. 78-82.

4. Абакумова И. В., Кагермазова Л. Ц. Смыслообразование как фактор инициации ценностно-смысловых установок в процессе формирования антиэкстремистской идеологии // Российский психологический журнал. - 2011. - Т. 8. - № 3. - С. 11-20.

5. Абакумова И. В., Кагермазова Л. Ц. Этническая толерантность как взаимодействие культур // Вестник Дагестанского государственного университета. - 2013. - № 4. - С. 248-253.

6. Абакумова И. В., Кагермазова Л. Ц., Ермаков П. Н. Технологии направленной трансляции смыслов в практике учебного процесса. Монография. - М., 2016.

7. Абакумова И. В., Кореневская М. Е., Левшина А. А. Формирование гражданской идентичности личности в условиях муниципального образовательного пространства г. Ростова-на-Дону // Всероссийская научно-практическая конференция «Личность в культуре и образовании: психологическое сопровождение, развитие, социализация». Ростов н/Д, 2014. - № 2. - С. 310-314.

8. Абакумова И. В., Лунин С. Л. Особенности адаптации трудовых мигрантов разной этноконфессиональной принадлежности // От истоков к современности. - М., 2015. - С. 261-263.

9. Кагермазова Л. Ц. Психологическое сопровождение социально-психологической адаптации студентов-мигрантов // Миграционные процессы в России: проблемы адаптации и интеграции мигрантов. Сборник материалов Всероссийской научно-практической видеоконференции и расширенного заседания Общественно-консультативных советов при УФМС России по Ставропольскому краю, Республике Северной Осетии-Алании и Кабардино-Балкарской Республике. - Ставрополь, 2014. - С. 102-105.

10. Кагермазова Л. Ц. Формирование готовности к межкультурной коммуникации у студентов-мигрантов в поликультурной среде 
вуза // Известия Кабардино-Балкарского государственного университета. - 2014. - T. IV. - № 2. - C. 101-103.

11. Кагермазова Л. Ц., Горшкова Л. М., Барабаш О. Д., Бордюгова Т. Н., Зиамбетов В. Ю., Штомпель Г. А., Эхаева Р. М., Масаева 3. В., Медведская Е. И., Микрюкова Т. Ю., Шамовская Т. В., Коваль Л. В., Майер С. Ф., Белова В. В., Герасименко Т. Л., Нисилевич А. Б., Стрижова Е. В. Психология и педагогика: на рубеже веков. Монография: в 2-х кн. - Одесса, 2015. - Кн. 2. - 191 c.

12. Кагермазова Л. Ц., Маламатов А. Х., Масаева 3. В. Межкультурная коммуникация как смыслотехника формирования толерантного сознания студентов вуза // Категория «социального» в современной педагогике и психологии. Материалы 4-й всероссийской научнопрактической конференции (заочной) с международным участием. Министерство образования и науки Российской Федерации; Тольяттинский государственный университет; Научно-образовательный центр «Перспектива». -Ульяновск, 2016. - С. 334-338.

13. Леонтьев Д. А. Психология смысла. - М.: Смысл, 1999. - 328 с.

14. Масаева 3. В., Кагермазова Л. Ц. Взаимосвязь психологической безопасности и национального образования // Педагогическое мастерство и педагогические технологии. - 2016. - № 2 (8). - С. 32-34.

15. Масаева 3. В., Кагермазова Л. Ц. Проблема взаимосвязи языка и межкультурной коммуникации // Развитие современной науки: теоретические и прикладные аспекты: сборник научных статей студентов, магистрантов, аспирантов, молодых ученых и преподавателей. Пермь, 2016. - С. 117-118.

16. Фоменко В. Т., Абакумова И. В. Ценностно-смысловые установки как компонент формирования антитеррористического мышления // Российский психологический журнал. - 2010. - Т. 7. - № 5-6. - С. 127-133.

17. Annett M., Kilshow D. Mathematical ability and lateral asymmetry // Cortex. - 1992. - V. 18.

18. Burke B. F., Chrisler J. C. The creative thinking, environmental frustration \& self-concept of left \& right-handers // Creativity Research J. - 1999. - no. 2.

19. Cattel R. B., Eber H. W., Tatsuoka M. M. Handbook for the 16 personality factor questionnaire. - Champaigh, II.: IPAT, 1998. - no. 6.

20. Holland J. L. Making vocation choices: A theory of vocational personalities and work environments. - N. Y.: Englewood Cliffs, 1995. - no. 8.

\section{References}

1. Abakumova I. V. Psikhologicheskie tekhnologii formirovaniia antiterroristicheskikh tsennostei v molodezhnoi srede [Psychological technologies 
of forming anti-terrorist values in the youth environment]. Rossiiskii psikhologicheskii zhurnal - Russian Psychological Journal, 2010, V. 7, no. 5-6, pp. 23-26.

2. Abakumova I. V., Grishina A. V. Otnoshenie studentov k migrantam kak faktor i pokazatel' etnokonfessional'nykh ustanovok sovremennoi molodezhi [Students' relation to migrants as a factor and indicator of ethnic and religious attitudes of modern young people]. Rossiiskii psikhologicheskii zhurnal - Russian Psychological Journal, 2013, V. 10, no. 3, pp. 22-28.

3. Abakumova I. V., Ermakov P. N. O stanovlenii tolerantnosti lichnosti v polikul'turnom obrazovanii [On the issue of the formation of tolerance in multicultural education]. Voprosy psikhologii-Approaches to Psychology, 2003, no. 3, pp. 78-82.

4. Abakumova I. V., Kagermazova L. Ts. Smysloobrazovanie kak faktor initsiatsii tsennostno-smyslovykh ustanovok v protsesse formirovaniia antiekstremistskoi ideologii [Sense-creation as a factor in the initiation of sense-value attitudes in the process of forming anti-extremist ideology]. Rossiiskii psikhologicheskii zhurnal - Russian Psychological Journal, 2011, V. 8, no. 3, pp. 11-20.

5. Abakumova I. V., Kagermazova L. Ts. Etnicheskaia tolerantnost' kak vzaimodeistvie kul'tur [Ethnic tolerance as the interaction of cultures]. Vestnik Dagestanskogo gosudarstvennogo universiteta-Bulletin of Dagestan State University, 2013, no. 4, pp. 248-253.

6. Abakumova I. V., Kagermazova L. Ts., Ermakov P. N. Tekhnologii napravlennoi transliatsii smyslov $v$ praktike uchebnogo protsessa [The technology of the directed sense transmission in the educational process]. Moscow, 2016.

7. Abakumova I. V., Korenevskaia M. E., Levshina A. A. Formirovanie grazhdanskoi identichnosti lichnosti v usloviiakh munitsipal'nogo obrazovatel'nogo prostranstva g. Rostova-na-Donu [The formation of civic identity in the municipal educational space of Rostov-onDon]. Vserossiiskaia nauchno-prakticheskaia konferentsiia «Lichnost' v kul'ture i obrazovanii: psikhologicheskoe soprovozhdenie, razvitie, sotsializatsiia» [Proc. the All-Russian Theoretical and Practical Conference "Personality in culture and education: psychological support, development, and socialization"]. Rostov-on-Don, 2014, no. 2, pp. 310-314.

8. Abakumova I. V., Lunin S. L. Osobennosti adaptatsii trudovykh migrantov raznoi etnokonfessional'noi prinadlezhnosti: Ot istokov k sovremennosti [Features of adaptation of labour migrants of various ethnoses and religions: From the origins to the present]. Moscow, 2015, pp. 261-263.

9. Kagermazova L. Ts. Psikhologicheskoe soprovozhdenie sotsial'no-psikhologicheskoi adaptatsii studentov-migrantov [Psychological support of socio- 
psychological adaptation of students-migrants]. Migratsionnye protsessy v Rossii: problemy adaptatsii i integratsii migrantov. Sbornik materialov Vserossiiskoi nauchno-prakticheskoi videokonferentsii i rasshirennogo zasedaniia Obshchestvenno-konsul'tativnykh sovetov pri UFMS Rossii po Stavropol'skomu kraiu, Respublike Severnoi Osetii-Alanii i Kabardino-Balkarskoi Respublike [Proc. the All-Russian Theoretical and Practical Conference and an extended meeting of the Public Advisory Council at the Federal Migration Service of Russia in Stavropol Krai, the Republic of North Ossetia-Alania, and the Republic of Kabardino-Balkaria"Migration processes in Russia: problems of adaptation and integration of migrants"]. Stavropol, 2014, pp. 102-105.

10. Kagermazova L. Ts. Formirovanie gotovnosti k mezhkul'turnoi kommunikatsii u studentov-migrantov v polikul'turnoi srede vuza [The formation of readiness to intercultural communication in students-migrants in the multicultural environment of the University]. Izvestiia Kabardino-Balkarskogo gosudarstvennogo universiteta-Proceedings of the Kabardino-Balkarian State University, 2014, V. IV, no. 2, pp. 101-103.

11. Kagermazova L. Ts., Gorshkova L. M., Barabash O. D., Bordiugova T. N., Ziambetov V. Iu., Shtompel' G. A., Ekhaeva R. M., Masaeva Z. V., Medvedskaia E. I., Mikriukova T. Iu., Shamovskaia T. V., Koval' L. V., Maier S. F., Belova V. V., Gerasimenko T. L., Nisilevich A. B., Strizhova E. V. Psikhologiia i pedagogika: na rubezhe vekov [Psychology and pedagogy: at the turn of the century]. Odessa, 2015. $191 \mathrm{p}$.

12. Kagermazova L. Ts., Malamatov A. Kh., Masaeva Z. V. Mezhkul'turnaia kommunikatsiia kak smyslotekhnika formirovaniia tolerantnogo soznaniia studentov vuza [Intercultural communication as a sense technique for the formation of tolerant consciousness in students]. Kategoriia "sotsial'nogo» v sovremennoi pedagogike i psikhologii. Materialy 4-i vserossiiskoi nauchnoprakticheskoi konferentsii (zaochnoi) s mezhdunarodnym uchastiem [Proc. the 4th All-Russian Theoretical and Practical Conference (in absentia) with International Participation "The category of "the social" in modern pedagogy and psychology"]. Ulyanovsk, 2016, pp. 334-338.

13. Leont'ev D. A. Psikhologiia smysla [The psychology of sense]. Moscow, Smysl Publ., 1999. 328 p.

14. Masaeva Z. V., Kagermazova L. Ts. Vzaimosviaz' psikhologicheskoi bezopasnosti i natsional'nogo obrazovaniia [The relationship between psychological security and national education]. Pedagogicheskoe masterstvo i pedagogicheskie tekhnologii - Pedagogical Skills and Educational Technology, 2016, no. 2 (8), pp. 32-34.

15. Masaeva Z. V., Kagermazova L. Ts. Problema vzaimosviazi iazyka i mezhkul'turnoi kommunikatsii // Razvitie sovremennoi nauki: teoreticheskie 
RUSSIAN PSYCHOLOGICAL JOURNAL • 2016 VOL. 13 \# 3

i prikladnye aspekty [The relationship between language and intercultural communication: The Development of modern science: theoretical and applied aspects]. Perm, 2016, pp. 117-118.

16. Fomenko V. T., Abakumova I. V. Tsennostno-smyslovye ustanovki kak komponent formirovaniia antiterroristicheskogo myshleniia [Sense-value attitudes as a component of the formation of antiterrorist thinking]. Rossiiskii psikhologicheskii zhurnal - Russian Psychological Journal, 2010, V. 7, no. 5-6, pp. 127-133.

17. Annett M., Kilshow D. Mathematical ability and lateral asymmetry. Cortex, 1992, V. 18.

18. Burke B. F., Chrisler J. C. The creative thinking, environmental frustration \& self-concept of left \& right-handers. Creativity Research J., 1999, no. 2.

19. Cattel R. B., Eber H. W., Tatsuoka M. M. Handbook for the 16 personality factor questionnaire. Champaigh, Il.: IPAT, 1998, no. 6.

20. Holland J. L. Making vocation choices: A theory of vocational personalities and work environments. N. Y.: Englewood Cliffs, 1995, no. 8. 